\title{
Wrocławski Budżet Obywatelski. Teraźniejszość i przyszłość
}

\#Wrocławski Budżet obywatelski \#budżet obywatelski \#partycypacja \#decentralizacja \#Wrocław Civic Budget \#civic budget \#participation \#decentralization

Artykuł analizuje rozwój Wrocławskiego Budżetu Obywatelskiego (WBO). Autor zwraca uwagę na proces tworzenia, zatwierdzania i realizacji wybranych projektów. Program WBO skierowany jest przede wszystkim do mieszkańców miasta, dąży do ich większej aktywizacji i zaangażowania w jego codzienne sprawy. Artykuł prezentuje szczegółowe dane statystyczne o liczbie zainteresowanych programem mieszkańców oraz o środkach przeznaczanych z budżetu miasta na WBO. Rozważania zostały wzbogacone w plany kolejnych edycji programu. Mimo wielkiego sukcesu pojawiają się pewne kontrowersje dotyczące WBO - m.in. w mediach. Niemniej z każdą edycją rośnie liczba zatwierdzonych projektów, a tym samym coraz więcej wrocławian angażuje się w program.

The article analyzes the development of the Wrocław Civic Budget (WBO). It focuses on the process of creating, approving and implementing selected projects. The WBO program is targeted primarily at the residents of the city and it is intended to activate them and increase their involvement in the city's daily matters. The article presents detailed statistical data on the number of inhabitants interested in the program and on the resources allocated from the city budget on the WBO. Moreover, it describes the plans for the following editions of the program. Despite its great success, some controversies concerning WBO have appeared, though, also in the media. Nevertheless, the number of approved projects is increasing with each edition, year by year, and thus more and more inhabitants of Wrocław get involved in the program.

Miasto. Pamięć i Przyszłość 1 (2017) ISSN 2543-621X

\section{OPEN ACCESS}

Citation: Świerczewski B., Wrocław Civic Budget: present and future, "Miasto. Pamięć i Przyszłość: Wrocławski Rocznik Samorządowy" - No 1

https://doi.org/10.xxxxx

Editor: Katarzyna Uczkiewicz

Received: October, 2016

Accepted: December, 2016

Published: December, 2016

Copyright: (c) Ośrodek „Pamięć i Przyszłość" This is an open access article distributed under the terms of the Creative Commons Attribution-ShareAlike Licence, which permits unrestricted use, distribution, and reproduction in any medium, provided the original author and source are credited, with indications if any changes are made. All derivative works must be licensed under the same licence.

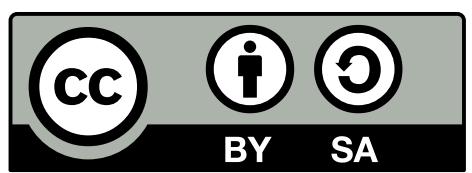




\section{Wrocławski Budżet Obywatelski. Teraźniejszość i przyszłość*}

*Artykuł powstał na przełomie sierpnia i września 2016 r.

\section{Wstęp}

Budżet obywatelski (wymiennie: budżet partycypacyjny) - to proces, który umożliwia mieszkańcom dyskusję i bezpośredni wpływ na decyzje dotyczące przeznaczenia części budżetu gminnego na przedsięwzięcia zgłoszone i wybrane bezpośrednio przez obywateli miasta.

Historia budżetów partycypacyjnych sięga swoimi korzeniami lat osiemdziesiętych XX w. Pierwszy raz narzędzie takie zostało zastosowane w mieście Porto Alegre (Brazylia). Obecnie taka forma współuczestnictwa mieszkańców w zarządzaniu miastem stosowana jest w wielu krajach na całym świecie. Choć tematyka budżetów obywatelskich została wielokrotnie opisana, to nie istnieje jeden powszechnie obowiązujący model budżetu partycypacyjnego. Tak samo jak nie istnieje w Polsce jeden konkrety przepis, na podstawie którego takie rozwiązanie można wdrożyć. Wszystko zależy od tego, w jakim celu się go wprowadza i jakim celom ma służyć.

Wrocławski Budżet Obywatelski (WBO) jest projektem nastawionym przede wszystkim na

Miasto. Pamięć i Przyszłość 1 (2016) ISSN 2543-621X

105 aktywizację mieszkańców. Urząd Miejski Wrocławia, dając mieszkańcom możliwość decydowania o ważnych dla nich inwestycjach, liczy na:

- wzmocnienie postaw obywatelskich i współodpowiedzialności za miasto,

- pokazanie mieszkańcom mechanizmów funkcjonowania Wrocławia,

- poznanie potrzeb wrocławian.

\section{Porto Allegre 1989 vs. Wrocław 2013}

W Porto Alegre w 1989 r., wprowadzono pierwszy (w mieście i na świecie) budżet partycypacyjny. Jak wtedy wyglądało te brazylijskie miasto? Populacja to ok. 900 tys. mieszkańców ${ }^{1}$. Do bieżącej wody i możliwości odprowadzania ścieków dostęp ma ok. 75\% populacji². W mieście funkcjonowało 29 szkół publicznych ${ }^{3}$. Miasto ma duże problemy z korupcją i nierówną redystrybucją środków. Warto w tym miejscu dodać, że od lat dziewięćdziesiątych budżety partycypacyjne stały

1. https://en.wikipedia.org/wiki/Porto_Alegre

2. Deepti Bhatnagar, Animesh Rathore, Magüi Moreno Torres, Parameeta Kanungo, Participatory budgeting in Brazil http://siteresources.worldbank.org/INTEMPOWERMENT/Resources/14657. Partic-Budg-Brazil-web.pdf

3. 72 Frequently Asked Questions about Participatory Budgeting, s. 24, http://unhabitat.org/ books/72-frequently-asked-questionsabout-participatory-budgeting/ 
się niemal obligatoryjnym narzędziem w samorządach brazylijskich4.

We Wrocławiu 2013 rok był pilotażowym rokiem budżetu partycypacyjnego. Jak wtedy wyglądało to polskie miasto? Populacja to nieco ponad 632 tys. mieszkańców ${ }^{5}$. Z wodociągów miejskich korzysta 96,5\% populacji, a z kanalizacji 91,7\%6. W mieście funkcjonuje ok. 340 szkół publicznych? Budżet partycypacyjny jest wprowadzany w oparciu o istniejące przepisy prawne dotyczące konsultacji społecznych, a powodem jego wdrożenia jest chęć władz samorządowych, aby sprawdzić, jak takie narzędzie może wpływać na aktywizację mieszkańców i tworzenie postaw obywatelskich.

\section{Budżety partycypacyjne w Polsce}

Pierwszy budżet partycypacyjny w Polsce wdrożono w Sopocie w 2011r. W roku 2014 realizowało go już 88 miast $^{8}$. Ta liczba stale, z roku na rok, rośnie. Jednocześnie każdy z tych budżetów w mniejszym lub większym stopniu się różni od9.

4. Porto Alegre and the participatory budget: civic education, politics and the possibilities for replication, s. 9, http://fimforum.org/en/library/Porto_Alegre_and_the_Participatory_Budget.pdf

5. Rocznik statystyczny Wrocławia 2014, http://wroclaw.stat.gov. pl/publikacje-i-foldery/roczniki-statystyczne/rocznik-statystyczny-wroclawia-2014,3,2.html

6. Ibidem,

7. Ibidem

8. Marta Szaranowicz-Kusz, Budzet partycypacyjny w Polsce, s. 2 (data data i miejsce wydania) http://orka.sejm.gov.pl/WydBAS. nsf/0/E2A1331AC540CD42C1257F3F00432714/\$file/Infos_205. pdf.

9. http://bp.partycypacjaobywatelska.pl/

10. Po wyborach w roku 2015 i zmianach w ministerstwie strony zostały zarchiwizowane i jako takie są obecnie dostępne. Autorowi nie udało się znaleźć też informacji na oficjalnych portalach rządowych na temat budżetów partycypacyjnych.

11. https://mac.gov.pl/budzet-partycypacyjny

12. Marta Szaranowicz-Kusz, op.cit.

13. http://uchwaly.um.wroc.pl/uchwala.aspx?numer=XIX/387/15
W polskim systemie prawnym nie istnieją przepisy precyzyjnie określające prawne podstawy wdrażania i funkcjonowania budżetów partycypacyjnych. Ministerstwo Administracji i Cyfryzacji na swoich stronach internetowych twierdziło 10, że „Wprowadzenie budżetu partycypacyjnego jest zgodne z obowiązującym w Polsce prawem. Mieści się w jego ramach jako „umowa społeczna" zawierana między mieszkańcami i radnymi..."11. Biuro Analiz Sejmowych w analizie ze stycznia 2016 r. podaje, że „Jeśli burmistrz wyrazi wolę wprowadzenia bp [budżetu partycypacyjnego - uzup. B.Ś.], to zwykle realizuje go zgodnie z ustawą z 8 marca 1990 r. o samorządzie gminnym, której art. 5a przewiduje, że w sprawach ważnych dla gminy mogą zostać przeprowadzone konsultacje z mieszkańcami”12.

Z tych powodów we Wrocławiu budżet partycypacyjny opiera się z jednej strony na umowie społecznej właśnie, umowie między mieszkańcami, prezydentem a radnymi, która potwierdzana jest coroczną ewaluacją zasad WBO. Biorą w niej udział mieszkańcy, organizacje pozarządowe, (NGO), radni i urzędnicy. Z drugiej na przepisach prawa. A konkretnie:

- corocznej uchwale budżetowej miasta, w której radni potwierdzają kwotę na daną edycję budżetu partycypacyjnego.

- uchwale w sprawie konsultacji ogólnomiejskich $^{13}$, na podstawie której organizowane jest głosowanie nad projektami.

- uchwale budżetowej, w której zadania mybrane przez mieszkańców, są zapisywane jako konkretne inwestycje na kolejny rok budżetowy.

Miasto. Pamięć i Przyszłość 1 (2016) ISSN 2543-621X 
Jak zostało to powiedziane wyżej, inne miasta radzą sobie z tą tematyką w różny sposób i opierają swoje działania zarówno na innych zapisach Ustawy o Samorządzie Gminnym, jak i innych szczegółowych przepisach prawa miejscowego.

\section{Historia WBO}

Jak wspomniano wyżej, historia wrocławskiego budżetu partycypacyjnego zaczyna się w 2013 r. Jednak rzeczywiste prace koncepcyjne nad tym projektem zaczęły się już w drugiej połowie roku 2012. Wtedy to ówczesny radny Jerzy Michalak zaprezentował prezydentowi Wrocławia Rafałowi Dutkiewiczowi możliwość zrealizowania takiego projektu we Wrocławiu. Jednostką, która miała realizować zadanie, zostało Biuro Rady Miejskiej Urzędu Miejskiego Wrocławia, kierowane przez Marcina Szelocha. Koordynatorem tego projektu został autor niniejszego artykułu. BRM miało bogate doświadczenia dotyczące projektów partycypacyjnych prowadzonych na styku urzędu i mieszkańców. W minionych latach współrealizowało cykl debat o Wrocławiu. Prowadziło też cykliczne zajęcia dla młodzieży szkolnej dotyczące samorządu i samorządności wrocławskiej.

Prace rozpoczęto od zebrania doświadczeń innych polskich i zagranicznych miast realizujących już podobne projekty. Oprócz kwerendy w Biuletynach Informacji Publicznej, dostępnych opracowaniach papierowych dotyczących tego zagadnienia, dedykowanych stronach WWW czy mediach społecznościowych zorganizowano również wizytę studyjną w Poznaniu. Ten etap prac pozwolił określić wstępne ramy dla tego projektu, a także, co bardzo ważne, zmierzyć się z procedurami pozostającymi po stronie urzędu. Przyjęty we Wrocławiu sposób realizacji pilotażu budżetu partycypacyjnego odbiega od modeli przyjmowanych w innych polskich miastach. Realizatorzy tego projektu wyszli z założenia, że zamiast skupiać się na pracy nad kartką papieru i wymyślaniem razem z mieszkańcami kolejnych punktów regulaminu, należy zaproponować im pewne rozwiązanie, które poprzez pilotaż zostanie poddane dużej dyskusji. Przyjęty sposób postępowania zapewnił bardzo duży udział mieszkańców w dyskusji o tym projekcie. Zasady pilotażu WBO2013 były zatem oparte na doświadczeniach innych miast, rozmowach z ekspertami ${ }^{14}$. Zostały też nieco zmodyfikowane po kilku spotkaniach dla mieszkańców, organizowanych przez aktywistów miejskich i środowiska polityczne.

Taki sposób procedowania stał się zdaniem aktywistów jedną z kluczowych z punktu widzenia ideologii budżetu partycypacyjnego wad wrocławskiego rozwiązania - brak wspólnego z mieszkańcami ustalenia zasad tego procesu. Sprawa ta była w związku z tym najczęściej podnoszona przy okazji dyskusji, publikacji, podsumowań. Jednak czy wada ta nie była w rzeczywistości pozorna? Pilotaż jako taki był właśnie dyskusją na temat tego, jak mieszkańcy widzą możliwość funkcjonowania takiego rozwiązania we Wrocławiu. Wzięło w niej udział prawie 60 tys. mieszkańców, ukazała się niezliczona liczba artykułów w prasie lokalnej, a efektem działań były dziesiątki uwag i duża frekwencja
Miasto. Pamięć i Przyszłość 1 (2016) ISSN 2543-621X

107
14. M.in. z Wojciechem Kębłowskim. 
na spotkaniach podsumowujących pilotaż. Spotkaniach, które stały się podstawą wypracowania zasad WBO2014. Organizatorzy procesu od początku zdawali sobie sprawę z faktu, że nie ma możliwości, aby przenieść rozwiązanie stosowane w jednym lub drugim mieście i zacząć je realizować. Pilotaż był więc formą konsultacji zasad WBO, ale konsultacji, które miały równocześnie nakłonić mieszkańców, aby zaangażowali się w ten projekt. I jak pokazują dane, takie założenie się sprawdziło we Wrocławiu.

\section{Pilotaż WBO 2013}

Zasady WBO2013 zostały ogłoszone przez prezydenta Rafała Dutkiewicza i radnego Jerzego Michalaka 19 marca 2013r ${ }^{15}$. Na realizację wskazanych przez mieszkańców zadań prezydent przeznaczył najpierw 2 mln zł by następnie zwiększyć kwotę do $3 \mathrm{mln}$ zł.

Na złożenie projektu mieszkańcy mieli miesiąc. Przez cały kwiecień urząd zorganizował trzy spotkania z mieszkańcami, w trakcie których tłumaczono zasady WBO oraz odpowiadano na pytania, jak wypełnić formularze, skąd pozyskać informacje o kosztach, gruntach miejskich itp. Każdy projekt mógł być złożony przez grupę do 15 osób, a jego wartość nie mogła przekraczać 500 tys. zł. Istotne było, że kwota na zadanie miała być proponowana przez mieszkańców. Do ich zdań należało też określenie składowych danego projektu z ogólnym rozbiciem na kwoty. Każdy z projektów musiał być zlokalizowany na terenie gminnym. Projekty mogły dotyczyć wyłącznie inwestycji, ponieważ

15. http://www.gazetawroclawska.pl/artykul/786343,dutkiewicz-do-wydania-sa-2-mln-zl-wroclawianie-zdecyduja-na-co-glosuj,id,t. html.

16. http://wroclaw.wyborcza.pl/wroclaw/1,35771,13857324,Obywatelu_zawalcz_o_swoj_wniosek_do_budzetu_obywatelskiego_. html. środki przeznaczone na ich realizację pochodziły z budżetu inwestycyjnego.

W ciągu miesiąca zgłoszono w sumie 242 pomysły. Najwięcej - 213 - zaproponowanych zostało przez grupy mieszkańców, 29 to inicjatywy organizacji pozarządowych i aktywistów. Zdecydowana większość wniosków dotyczyła szeroko rozumianej rekreacji i zieleni - 92, następne były remonty chodników i ulic oraz projekty rowerowe $-63^{16}$. Projekty były najczęściej podpisywane przez 3-5 osób, choć zdarzały się i takie, które podpisało kilkadziesiąt, a nawet kilkaset osób. Ich weryfikacja przez urzędników trwała do 22 maja. Zajmowały się tym merytoryczne jednostki Urzędu Miejskiego Wrocławia. Następnie wszystkie projekty były kierowane do powołanego przez przewodniczącego Rady Miejskiej Wrocławia Jacka Ossowkiego specjalnego zespołu. W jego skład wchodzili przedstawiciele prezydium rady miejskiej wskazani przez przewodniczącego; przewodniczący komisji: infrastruktury komunalnej, ds. osiedli, sportu i rekreacji; przedstawiciele departamentów urzędu odpowiedzialnych za merytorykę opisaną w projektach oraz przedstawiciel Wrocławskiej Rady Pożytku Publicznego. Pozytywnie zweryfikowano ok. połowy zgłoszonych projektów.

Głosowanie nad projektami odbyło się między 4 a 17 czerwca. Pierwotnie, w początkach marca, zakładano, że pod głosowanie trafi tylko 20 projektów rekomendowanych przez zespół. Takie rozwiązanie wynikało też z technicznego rozwiązania, aby na jednej karcie do głosowania zmieścić wszystkie pomysły, spośród których

Miasto. Pamięć i Przyszłość 1 (2016) ISSN 2543-621X 
mieszkańcy mieliby wybrać te, które ich zdaniem były najważniejsze. Jednak w obliczu tak dużego zainteresowania wrocławian, decyzji o zwiększeniu kwoty na pilotaż WBO do $3 \mathrm{mln}$ zł, wycofano się z pomysłu ograniczania liczby zadań poddawanych pod głosowanie. Ostatecznie to mieszkańcy mieli sami wybrać najważniejsze zadania spośród tych, które zostały pozytywnie zweryfikowane. Głosowanie odbyło się z wykorzystaniem internetu, ale było również możliwe dla osób, które wolały głosować na kartach papierowych. Było ono formą konsultacji, zarządzonych odrębną uchwałą Rady Miejskiej Wrocławia ${ }^{17}$. Wyniki głosowania ogłoszono 24 czerwca 2013 r.

W głosowaniu wzięło udział 51708 osób z czego głosów ważnych oddano 51593 a nieważnych 114. Liczba głosów oddanych przez internet to 49849 a w formie papierowej 1 859. Po zakończeniu głosowania losowo wybraną grupę 300 głosów skontrolowano, ale nie stwierdzono żadnych uchybień. Głosy uznane za nieważne były takimi z powodu podania niekompletnego lub nieprawidłowego numeru PESEL, oddania głosu dwa razy - w formie elektronicznej i papierowej. Zidentyfikowano też jeden głos oddany z wykorzystaniem nieprawdziwych danych osobowych ${ }^{18}$. Do realizacji wybrano osiem projektów.

\section{Kontrowersje}

Pilotaż WBO spotkał się z bardzo dużym zainteresowaniem lokalnych mediów, aktywistów i mieszkańców. Od marca do czerwca ukazało się kilkadziesiąt artykułów prasowych, odbyło kilka

Miasto. Pamięć i Przyszłość 1 (2016) ISSN 2543-621X 109 audycji radiowych i telewizyjnych na temat tego projektu. Głos w tym temacie zabierano w mediach społecznościowych, na forach miejskich i osiedlowych $^{19}$ oraz w trakcie debat publicznych, które przyciągały obserwatorów i dyskutantów²0. Wypowiedzi w znacznej mierze krytycznie, odnosiły się do sposobu wdrażania i funkcjonowania WBO ${ }^{21}$, powątpiewano, czy uda się zebrać choćby 100 wniosków od mieszkańców²2, obarczając winą za taki stan rzeczy brak możliwości składania projektów przez samorządy osiedlowe²3. Najczęściej pojawiały się jednak uwagi do niskiej kwoty w pilotażu WBO201324 oraz braku wspólnego z mieszkańcami ustalenia zasad tego projektu.

Kolejne kontrowersje dotyczyły wyników weryfikacji projektów i sposobów głosowania. Zacznijmy od tego drugiego zagadnienia. Było ono opisywane przez media; głos w tej sprawie zabierali również radni miejscy ${ }^{25}$. W myśl paragrafu 3 uchwały Rady Miejskiej Wrocławia dotyczącej konsultacji26, mogły brać w nich udział osoby posiadające czynne prawo wyborcze i stale

17. http://uchwaly.um.wroc.pl/uchwala.aspx?numer=XLIV/1074/13 18. Lolita Dobuzibiorska, lat 116 - autentyczny zapis z zachowaną oryginalną pisownią.

19. Wrocławskie forum w ramach Skyscrapercity, forów osiedlowych itp.

20. http://www.krytykapolityczna.pl/kluby-kp/wroclaw/20130329/ partycypacja-nie-konkurs-grantowy.

21. http://wroclaw.wyborcza.pl/wroclaw/1,36743,13643913,Obywatelski_czy_partycypacyjny_na_ile_i_czy_rzeczywiscie_html.

22. http://wroclaw.wyborcza.pl/wroclaw/1,35771,13681326,Prawdziwy_budzet_obywatelski_czy_raczej_totolotek_.html.

23. Ibidem.

24. http://www.gazetawroclawska.pl/artykul/787314,budzet-obywatelski-kwota-jest-niepowazna-a-wroclaw-mami-opinie-publiczna-list,id,t.html.

25. http://www.gazetawroclawska.pl/artykul/911886,glosowanie-nad-projektami-budzetu-obywatelskiego-niewazne,id,t.html.

26. http://uchwaly.um.wroc.pl/uchwala. aspx?numer=XXXVII/2437/05. 
zamieszkujące na terenie Wrocławia. Głosując, każdy mieszkaniec musiał podać swoje imię, nazwisko oraz nr PESEL.

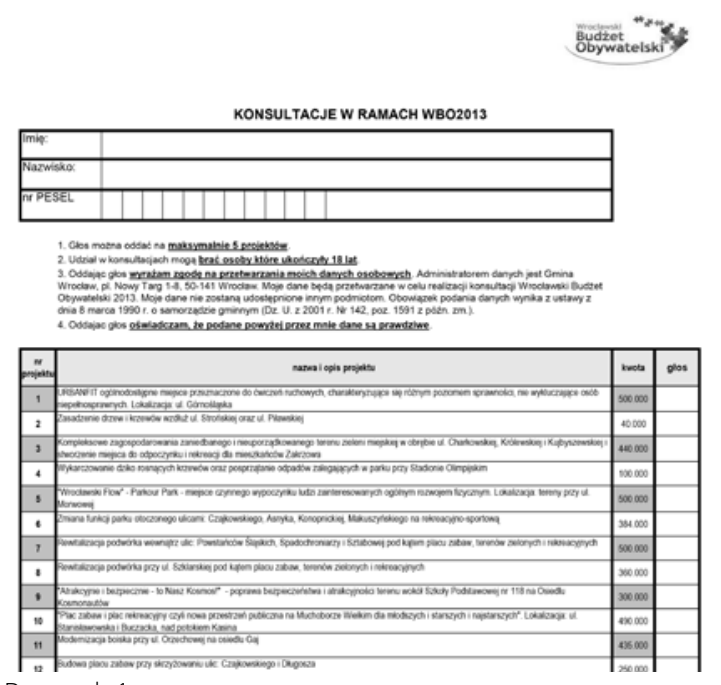

Rysunek 1

Taki zapis uchwały kłócił się jednak z zapisami Ustawy o Samorządzie Gminnym, która precyzuje, że w konsultacjach mogą brać udział mieszkańcy gminy. Ustawa nie wspomina słowem na temat zameldowania lub innych obostrzeń. WBO od samego początku było pomyślane jako projekt dla użytkowników miasta, a nie wyłącznie osób w nim zameldowanych. Takie podejście wynikało m.in. z chęci, aby głosować mogli też studenci czy osoby pracujące we Wrocławiu i mocno z nim związane.

Drugą kwestią były wyniki weryfikacji. Nie przeszło jej ponad 100 projektów ${ }^{27}$. Nie zostały one zweryfikowane pozytywnie z uwagi na m.in.: niezgodność z przepisami prawa, przekroczenie kwoty maksymalnej określonej dla jednego projektu, niegospodarność. Do tego dołożyły się też krótki czas na weryfikację, niewydolny system dystrybucji dokumentów, opierający się na długiej ścieżce obiegu, i przesyłania ich do danej (jednej) jednostki weryfikującej. W tych działaniach brakowało czasu oraz efektywnego i szybkiego przepływu wiedzy między jednostkami. To skutkowało niedokładnymi lub rozbieżnymi opiniami na dany temat, długimi dyskusjami na spotkaniu zespołu WBO i trudnościami w uzgadnianiu wspólnego, spójnego wyniku weryfikacji. Szczególnie stawato się to widoczne, kiedy na ostatnim spotkaniu zespołu weryfikującego jedna jednostka przedstawiała opinię negatywną, a druga pozytywną z uwagami. Wówczas z powodu napiętego kalendarza WBO2013 nie można już było dokładniej sprawdzić wszystkich składowych projektu. To wymagało wyciągnięcia wniosków na przyszłość. I stało się jednym z głównych elementów zmian w kolejnej edycji.

\section{Realizacja}

Mieszkańcy wybrali do realizacji 8 projektów, zlokalizowanych w różnych częściach Wrocławia. Projekty te dotyczyły głównie rekreacji i sportu: Nr 157 Przystosowanie obiektu sportowego do potrzeb futbolu amerykańskiego oraz rozgrywania meczów rugby, ultimate frisbee, lacrosse i piłki nożnej. Lokalizacja: Stadion MOSiR ul. Lotnicza 72; kwota: 495000 zł;

$\mathrm{Nr} 18$ "Atrakcyjnie i bezpiecznie - to Nasz Kosmos!" - projekt ma na celu poprawę bezpieczeństwa i atrakcyjności terenu wokół Szkoły Podstawowej nr 118 na osiedlu Kosmonautów; kwota: 300000 zł; 
Nr 53 "Osiedle na sportowo" - rewitalizacja i zapewnienie bezpieczeństwa na boisku przy ul. Osinieckiej na osiedlu Żerniki; kwota: 385000 zł;

Nr 69 Budowa Placu Sportów Miejskich w jednej z lokalizacji: Wzgórzec Słowiańskie, Wzgórze Andersa, plac Strzegomski. Będzie to obiekt sportowo-rekreacyjny o przeznaczeniu treningowym skierowany do mieszkańców oraz użytkowników miasta Wrocław. Otwarte miejsce do ćwiczeń dla mieszkańców w każdym wieku; kwota: 269900 zł;

Nr 20 Plac zabaw i plac rekreacyjny, czyli nowa przestrzeń publiczna na Muchoborze Wielkim dla młodszych, starszych i najstarszych, ulice Stanisławowska i Buczacka, nad potokiem Kasina; kwota: 490000 zł;

Nr 133 "Aktywni w rytm muzyki” - muzyczny plac zabaw dla ZS nr 20, ul. Kłodnicka 36; kwota: 400000 zł;

Nr 221 Zagospodarowanie terenu przy kościele, budowa chodnika, uporządkowanie zieleni, oświetlenie. Lokalizacja: ul. Żernicka 242, kwota: 73000 zł;

Nr 122 Zabezpieczenie kolekcji zabytkowych tramwajów niszczejących obecnie na tyłach zajezdni przy ul. Legnickiej, kwota: 500000 zł. Już wówczas, w pierwszej edycji, wyraźnie zaczęła się pojawiać pewna tendencja. Okazało się, że więcej szans na zdobycie projektu mają osiedla nie bardzo liczne, ale mniejsze. Dzieje się tak najprawdopodobniej przez fakt łatwiejszej komunikacji między mieszkańcami, co przekłada się na możliwość skupienia wokół projektu większej

Miasto. Pamięć i Przyszłość 1 (2016) ISSN 2543-621X

111 liczby osób. Osoby te mają większą zdolność pozyskiwania głosów. W WBO2013 osiedle Żerniki, liczące ok. 3,5 tys. osób zdobyło aż dwa projekty, a Ołbin liczący 39 tys. nie zdobył żadnego projektu.

Projekty wybrane w 2013 r. zostały zrealizowane w roku 2014, z wyjątkiem nr. 122, który zakończono w roku 2015, w zakresie remontu nadbudówki wagonu Maximum i zabezpieczenia, czyli schowania pod dach dawnej zajezdni przy ul. Legnickiej i Dąbie, kilku najbardziej wartościowych i najstarszych pojazdów komunikacji miejskiej.

\section{Ewaluacja}

Zaraz po zakończeniu głosowania urzędnicy zebrali ok. 100 ankiet od liderów projektów złożonych w pilotażu WBO2013. Dodatkowo zgromadzono ok. 60 e-maili z uwagami i pomysłami na kolejne edycje. Pracownicy prowadzący ten projekt zrobili też kwerendę w mediach społecznościowych, na forach osiedlowych czy ogólnomiejskich, zbierając dziesiątki kolejnych pomysłów na przyszłość. Wszystkie one zostały opublikowane w internecie. Zorganizowano też kolejne spotkania adresowane do zainteresowanych mieszkańców28, jak i odrębne do NGO, samorządów osiedlowych ${ }^{29}$. Efektem tych spotkań i rozmów były zasady WBO2014, wstępnie zarysowane w połowie grudnia 2013 r. ${ }^{30}$.

\section{WBO 2014}

Jak wspomniano wyżej, zasady pierwszego [nie licząc pilotażu] pełnego budżetu partycypacyjnego pojawiły się już w połowie 2013 r. Napisane zostały na podstawie przeprowadzonego

28. http://www.wroclaw.pl/ co-nowego-we-wroclawskim-budzecie-obywatelskim 29. http://www.wroclaw.pl/ przyszlosc-wroclawskiego-budzetu-obywatelskiego 30. http://www.wroclaw.pl/zasady-wbo-na-2014-rok 
pilotażu, zgromadzonych w trakcie jego trwania i po zakończeniu pomysłów, doświadczeń oraz spotkań ewaluacyjnych z mieszkańcami. Te ostatnie odbywały się zarówno w formule otwartej, dla wszystkich zainteresowanych, jak i eksperckiej. To, co zaproponowano w nowych zasadach, różniło się zarówno w kwestiach ilościowych (większa kwota - 20 mln zł, więcej spotkań z mieszkańcami, dłuższe terminy) jak i jakościowych (spotkania w różnych częściach miasta, dedykowana strona WWW, system obiegu dokumentów WBO oraz system nadzoru nad realizacją projektów).

Temat WBO nadal firmował radny Jerzy Michalak. Realizacją całego procesu zarządzał już jednak zespół złożony z pracowników Biura Rady Miejskiej i Biura Zarządzania Projektami31 Urzędu Miejskiego Wrocławia. Tym razem po opublikowaniu zasad WBO2014 rozpoczęto serię spotkań informacyjnych z mieszkańcami. Zrealizowano ich na tym etapie 11, w różnych częściach miasta. Spotkania odbywały się pomiędzy 8 stycznia a 18 lutego. Ich celem były przekazanie mieszkańcom informacji na temat WBO, pomoc przy wypełnianiu formularzy projektowych, pozyskiwaniu danych potrzebnych do skonkretyzowania projektu. Dodatkowo uruchomiono 22 centra informacyjne, zlokalizowane w większości w siedzibach Miejskiej Biblioteki Publicznej ${ }^{32}$. Ich zadaniem było uzupełniające informowanie mieszkańców w temacie budżetu

31. Karolina Woźniak, zastąpiona w połowie 2014 r. przez Katarzynę Szymczak-Pomianowską.

32. http://www.wroclaw.pl/rozmawia/centra-informacyjne-wbo.

33. Numer ten +48 717777777 daje mieszkańcom możliwość zapytania o różne szczegóły dotyczące funkcjonowania miasta. Jeśli osoba na centrali nie jest w stanie udzielić pełnej informacji, prosi o wsparcie drugą linię. W wypadku WBO byli to pracownicy merytorycznie zajmujący się tym procesem. partycypacyjnego, realizowanego we Wrocławiu. Kolejną pomocą była możliwość zapytania o szczegółowy WBO pod telefonicznym numerem informacyjnym urzędu³. Od 2014 r. działać zaczęła też dedykowana strona internetowa www.wroclaw.pl/wbo Pełniła ona funkcje informacyjne, służyła do głosowania oraz składania projektów.

Kolejnym rozwiązaniem informatycznym był elektroniczny system obiegu projektów, dzięki któremu wszystkie jednostki merytoryczne mogły się z nimi zapoznawać w tym samym momencie, a dodatkowo gromadzić w nim dane pomagające przy późniejszej weryfikacji. Pod koniec roku 2014 zaczął też działać elektroniczny system nadzoru nad realizacją projektów wybranych przez mieszkańców. Dzięki niemu informacje o etapach realizacji projektów przez poszczególne jednostki urzędu znajdują się w jednym miejscu, a Wrocław stał się jedynym miastem nadzorującym realizację zadań wskazanych przez mieszkańców centralnie, w formie zarządzania projektami. W 2014 r. zaczęto też wprowadzać działania mające na celu integrację (jeśli chodzi o przepływ danych) wszystkich systemów elektronicznych, o których mowa była powyżej.

Projekty można było zgłaszać od 13 stycznia do 5 marca 2014 r. W tej edycji autorem projektu mogła być jedna osoba, nie była wymagana lista poparcia. Składając projekt, nie trzeba było być mieszkańcem Wrocławia, ale jedynie osobą pełnoletnią. Po raz kolejny nacisk położony został na użytkowników miasta i pomysły, w myśl

Miasto. Pamięć i Przyszłość 1 (2016) ISSN 2543-621X 
zasady, iż dobry pomysł się sam obroni, a ludzie na niego zagłosują bez względu na to, kto go złożył. Projekty mogły być małe - do 100 tys. zł, średnie - do 500 tys. Pzł i duże - do 1,5 m/n zł. W trakcie spotkań z mieszkańcami, na etapie ustalania zasad WBO2014, określono też, że na każdą pulę kwotową powinno się przyznać określoną sumę z całego WBO. Została ona ustalona procentowo, według liczby projektów w progach, ale na podstawie przeliczonych danych z pilotażu WBO2013. Tym samym na projekty małe przeznaczono $5 \mathrm{mln}$ zł; na średnie $8 \mathrm{mln}$ zł i na duże 7 $\mathrm{mln}$ zł. Takie rozwiązanie miało zapewnić przede wszystkim wyrównanie szans projektów małych i średnich w konkurowaniu o głosy z dużymi, bardziej nośnymi tematami. W zasadach uściślono, że składane przez liderów pomysły powinny być zlokalizowane na terenie miasta. Musiały być projektami inwestycyjnymi, remontowymi lub dotyczącymi utrzymania mienia gminnego. Wnioski projektowe nie mogły dotyczyć infrastruktury nienależącej do Gminy Wrocław ${ }^{34}$.

Tym razem mieszkańcy zaproponowali 481 projektów:

- rekreacja - 144 projektów,

- zadania na terenach edukacyjnych 43 projekty,

- zieleń miejska - 38 projektów,

- projekty dotyczące ruchu rowerowego - 37,

- projekty drogowe, parkingowe, piesze-116

- inne - 101.

Weryfikacja projektów przez urzędników trwała od 6 marca do 18 maja. Zaraz po pierwszym etapie weryfikacji i poinformowaniu o tym liderów oraz opublikowaniu wyników na stronie WWW rozpoczęła się druga tura spotkań z mieszkańcami. Trwała ona między 3 czerwca a 3 lipca. Był to czas przewidziany na dyskusję z liderami o projektach i wynikach weryfikacji. Do 14 lipca liderzy mieli czas na złożenie poprawek. Ale ten czas miał też służyć dyskusji na temat zgłoszonych zadań, ich prezentacji mieszkańcom - dlatego spotkania weryfikacyjne były otwartye dla wszystkich zainteresowanych. Po tym terminie wszystkie poprawione projekty zostały skierowane do ponownej weryfikacji. Trwała ona do 14 lipca do 30 sierpnia. Tym razem weryfikacja odbywała się w oparciu o system elektroniczny oraz spotkania wszystkich jednostek. W trakcie spotkań omawiany był każdy ze zgłoszonych projektów i na podstawie rozmów powstawał wynik weryfikacji. Zweryfikowane projekty trafiły do Zespołu Opiniującego. Do uczestnictwa w nim zostali zaproszeni przez prezydenta Wrocławia przewodniczący Komisji ds. Osiedli Rady Miejskiej Wrocławia, przedstawiciele Rady Miejskiej Wrocławia wskazani przez przewodniczącego Rady Miejskiej, przedstawiciele departamentów Urzędu Miejskiego Wrocławia odpowiedzialnych za merytoryczną stronę realizacji zgłoszonych projektów, przedstawiciel Wrocławskiej Rady Pożytku Publicznego, lider projektu, który w pilotażu WBO 2013 uzyskał największą liczbę głosów. Zespół Opiniujący przedstawił prezydentowi Wrocławia ostateczną listę pozytywnie zweryfikowanych projektów.

4 września Rada Miejska Wrocławia przyjęła uchwałę zarządzającą konsultacje w sprawie
Miasto. Pamięć i Przyszłość 1 (2016) ISSN 2543-621X

113
34. http://www.wroclaw.pl/rozmawia/wbo-2014-zasady. 
WBO2014. Jej załącznikiem była lista projektów, poddawanych pod głosowanie ${ }^{35}$.

Weryfikację z wynikiem pozytywnym przeszło 314 propozycji i tyle też zostało poddanych pod głosowanie mieszkańców. W przypadku 28 projektów okazało się, że są już realizowane lub przygotowywane do realizacji przez Gminę Wrocław w procedurach niezależnych od budżetu partycypacyjnego. 20 projektów zostało wycofanych przez liderów. Powodami wycofania były najczęściej powtórki w przedmiocie projektu lub przyjęta dla danego osiedla strategia - im mniej projektów tym większa szansa na wygraną. 119 projektów nie zostało poddanych pod głosowanie z uwagi na przekroczenie budżetu przewidzianego dla jednego projektu, fakt, że znajdowały się na terenie nienależącym do gminy Wrocław, niezgodność z planami miejscowymi, niegospodarność lub niezgodność z innymi przepisami prawa.

Głosowanie na projekty WBO2014 trwało od 15 do 28 września. Głosować można było elektronicznie i na kartach papierowych na maksymalnie trzy projekty. Głosować mogli pełnoletni mieszkańcy miasta, podając swoje imię, nazwisko, nr PESEL i oświadczając, że są mieszkańcami Wrocławia. Karty papierowe można było wrzucić do urn znajdujących się w czterech Centrach Obsługi Mieszkańca. Głosowało 153366 osób, z tego 128637 osób poprzez formularz on-line i 24729 osób poprzez formularz papierowy. Do realizacji wybrano 89 projektów, z czego 61 to

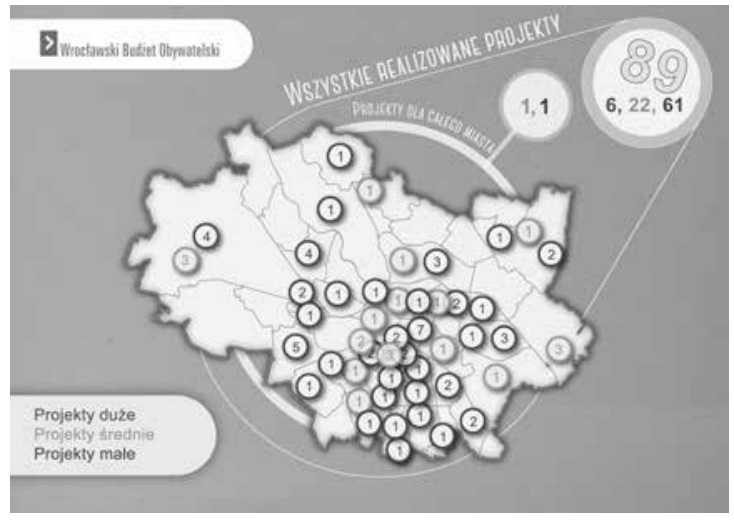

Rysunek 2

projekty małe, 22 średnie i 6 dużych. Rozmieszczenie projektów pokazuje poniższa mapa.

Po raz drugi potwierdziła się tendencja, że nie liczba mieszkańców na osiedlu decyduje o tym, czy projekt trafi do realizacji. Po raz kolejny mniejsze osiedla zyskały albo więcej projektów, albo większe projekty.

\subsubsection{Kontrowersje}

Pierwszym elementem, na który zaczęto zwracać uwagę już w grudniu 2013 r., była kwestia zasad WBO2014. Towarzystwo Upiększania Miasta Wrocławia, Wrocławska Inicjatywa Rowerowa, wsparte autorytetem Wojciecha Kębłowskiego, autora dwóch ewaluacji procesów budżetów partycypacyjnych w Polsce, podnosiły konieczność jeszcze większego upodmiotowienia mieszkańców i samorządów osiedlowych, przejrzystości i dalszego zwiększania kwoty na ten cel ${ }^{36}$.

Kolejnym tematem budzącym dyskusję już po zakończeniu głosowania był fakt, że do realizacji trafiły wszystkie małe projekty, do 100000 zł. Wśród nich taki, który zebrał jedynie 11 głosów. Stało się tak dlatego, że

35. http://uchwaly.um.wroc.pl/uchwala.aspx?numer=LXII/1579/14.

36. http://tumw.pl/

wroclawski-budzet-obywatelski-2014-nasza-opinia/\#more-4592.

Miasto. Pamięć i Przyszłość 1 (2016) ISSN 2543-621X 
poszczególne progi kwotowe określono z góry, posiłkując się danymi ilościowymi i kwotowymi z pilotażu WBO2013. Zespół zarządzający procesem WBO, wiedząc o tym od momentu zweryfikowania projektów, nie zaimplementował zmian. Podjęto taką decyzję z uwagi na uszanowanie zasad wypracowanych z mieszkańcami. Wówczas nikt nie spodziewał się, że jakikolwiek projekt mógłby mieć tak niskie poparcie. To spowodowało wprowadzenie minimum głosów, które musi uzyskać projekt w kolejnej edycji.

Nowością tej edycji był rozbudowany moduł dyskusji z mieszkańcami. O ile spotkania na etapie zgłaszania projektów dawały możliwość zapytania o zasady, terminy, dowiedzenia się, skąd pozyskać informacje potrzebne do złożenia projektu, o tyle spotkania, które odbyły się po pierwszym etapie weryfikacji, choć kluczowe dla przyszłości wielu projektów, zostały pominięte przez wielu liderów. Taka sytuacja uniemożliwiła dialog na temat wielu projektów. Tym samym część ze 119 negatywnie zweryfikowanych projektów pozbawiona została szansy na powrót na listę do głosowania.

Ostatnim elementem dotyczącym pierwszego, pełnego budżetu partycypacyjnego przeprowadzonego we Wrocławiu, budzącym kontrowersje, była kwestia zakresu realizowanych projektów. Część z nich na etapie przygotowania dokumentacji czy rozstrzygnięcia procedur przetargowych okazała się droższa, niż szacowano na początku. A ponieważ budżet całego WBO został bardzo konkretnie określony i podzielony na poszczególne zadania, nie było szansy na dokładanie środków. Dlatego w kilku przypadkach koniecznyne stało się ograniczenie zakresu prac. Takie zmiany zawsze odbywały się w porozumieniu z liderem. Jednak siłą rzeczy były one odbierane przez mieszkańców w sposób negatywny. W kilku wypadkach konieczne okazało się etapowanie prac. I tak z edycji 2014 wykonywano dokumentację projektową i rozpoczynano prace, jednocześnie informując lidera, że aby zakończyć projekt, konieczne będzie albo ponowne wystartowanie w następnych edycjach WBO (w zależności od tego, jakie środki będą potrzebne na zakończenie prac, lider mógł albo starać się o pozyskanie jednorazowo większej kwoty, albo podjąć decyzję, że będzie wnioskował o mniejsze kwoty, ale projekt przez to może być realizowany przez dłuższy czas), albo poszukiwanie środków na realizację z innych źródeł, poza WBO. Miało to wpływ na bardziej wnikliwą weryfikację projektów w kolejnych edycjach oraz negatywną weryfikację tych pomysłów, które zakładały budowę np. połowy chodnika.

\section{Realizacja}

Do realizacji mieszkańcy wybrali 89 projektów. Z początku było ich 87, a 2 znajdowały się na liście rezerwowej, ale po pół roku zaoszczędzone przy kilku projektach środki udało się skierować właśnie na potrzeby tych dwóch dodatkowych. Największy sukces odniósł projekt zakładający budowę pasów rowerowych w centrum miasta. Był on tym większy, że uzyskana liczba głosów była jedną z największych w Polsce wśród projektów pojawiających się w budżetach partycypacyjnych.
Miasto. Pamięć i Przyszłość 1 (2016) ISSN 2543-621X

115 
Większość projektów została zrealizowana do końca 2015 r. W wypadku kilku już w styczniu 2015 r. było jasne, że ich zakończenie przesunie się na rok 2016. Ostatecznie dwa z nich zostaną zakończone w roku 2017. O jednym z projektów warto wspomnieć w tym miejscu. Jest to projekt dotyczący budowy parku na Oporowie. Teren ten ma powierzchnię ok. 12 hektarów. W WBO przeszedł do realizacji z kwotą ok. 1,5 mln zł. Na etapie sporządzania dokumentacji technicznej okazało się, że trzeba uzyskać szereg uzgodnień w związku z bliskością rzeki Ślęzy, sieciami wysokiego napięcia, kolektorem ściekowym czy ogrodami działkowymi, które powinny zostać wygaszone, czy kwestiami gruntów rolnych, wymagających przekształcenia. Najpoważniejszą przeszkodą pozostały sieci wysokiego napięcia oraz kwestie odrolnienia. Są to kosztochłonne elementy, które mają duży wpływ na opóźnienia w realizacji. Projekt ten przez swoją skomplikowaną materię stał się jednym z ważniejszych poligonów dotyczących procedur przy weryfikacji pomysłów mieszkańców, ale i polem do sprawdzania wielu rozwiązań, mających na celu umożliwienie realizacji projektu bez zwiększania budżetu na ten cel. Projekt, podobnie jak wiele innych w tej i kolejnych edycjach WBO, był/jest bacznie nadzorowany przez liderów. Ci natomiast o wszelkich postępach i opóźnieniach skrupulatnie informują mieszkańców, ${ }^{37}$ co dla urzędu jest zarówno sporym wyzwaniem jak i zaletą.

\section{7. http://www.parkmamuta.pl/.}

38. http://wroclaw.wyborcza.pl/wroclaw/1,35771,13857324,Obywatelu_zawalcz_o_swoj_wniosek_do_budzetu_obywatelskiego_. html.

39. http://www.wroclaw.pl/files/files/WBO_pomysly_i_uwagi_zgloszone_w_roku_2014.pdf.

40. http://uchwaly.um.wroc.pl/uchwala.aspx?numer=231/15.

\subsubsection{Ewaluacja}

O zwiększeniu kwoty na WBO2014 mowa była już późną wiosną 2013 r. ${ }^{38}$. Po podaniu wyników głosowania zespół realizujący WBO rozpoczął zbieranie uwag od mieszkańców. Efektem tych działań była ponad setka uwag i pomysłów dotyczących kolejnych edycji39. Zostały one opracowane i przedstawione na kilku odrębnych spotkaniach adresowanych do mieszkańców, aktywistów, NGO, samorządów osiedlowych, radnych miejskich czy urzędników. Na podstawie tych rozmów doprecyzowano zasady kolejnej edycji budżetu partycypacyjnego - WBO2015.

Równocześnie prezydent Wrocławia zarządzeniem z dnia 15 stycznia 2015 r. powołał do życia społeczną radę ds. Wrocławskiego Budżetu Obywatelskiego ${ }^{40}$. W jej skład weszli przede wszystkim liderzy WBO2013, WBO2014, radni, naukowcy, urzędnicy. Rada jest ciałem doradczym prezydenta Wrocławia, powołanym na dwa lata. Opiekę nad nią sprawuje wiceprezydent Wrocławia Maciej Bluj. Do jej zadań należy doradzanie prezydentowi w zakresie współuczestnictwa mieszkańców w zarządzaniu miastem.

W kolejnej edycji budżetu partycypacyjnego zmienić się miały kwoty w progach projektowych na 150 tys. dla projektów małych, 500 tys. dla średnich i 2 mln dla dużych. Jednocześnie budżety poszczególnych progów miały być ustalane procentowo według liczby projektów w danym progu, ale miało to być ustalane dopiero w chwili ustalenia listy projektów poddawanych

Miasto. Pamięć i Przyszłość 1 (2016) ISSN 2543-621X 
pod głosowanie. Na etapie ewaluacji obiecano też, że przez rok 2015 będą się toczyły prace nad podzieleniem miasta na rejony i wyodrębnieniem na nie określonych kwot.

Elementem, na który dość często zwracali uwagę mieszkańcy, był brak możliwości kontaktu z liderem przez stronę WWW. To oraz dalsze usprawnienia, uproszczenia i dodatkowe funkcje również stały się elementem dalszych zmian WBO.

Rok 2015 to również pierwszy podział miasta na 10 rejonów WBO. Miały one na razie charakter wyłącznie porządkowy, ułatwiający organizację spotkań z mieszkańcami.

\section{WBO 2015}

Zasady WBO2015 opublikowane zostały na przełomie 2014 i 2015 r. Po ich wypracowaniu na podstawie wskazań mieszkańców zaprezentowano je radnym miejskim. Grono to nie wniosło żadnych uwag do nowej edycji budżetu partycypacyjnego.

15 stycznia ukonstytuowała się Wrocławska Rada ds. Budżetu Obywatelskiego. W trakcie swojego pierwszego spotkania również zapoznała się z zasadami WBO ${ }^{41}$ i szczegółowym harmonogramem na rok 2015. W trakcie roku rada spotka się jeszcze pięć razy, będzie dyskutować zarówno o projektach, sposobach weryfikacji, jak i głosowaniu, ewaluacji czy zasadach WBO na rok kolejny. Z każdego spotkania rady tworzona i publikowana jest notatka na stronie wroclaw.pl.

W ramach WBO2015 mieszkańcy mieli czas na składanie projektów pomiędzy 26 stycznia

Miasto. Pamięć i Przyszłość 1 (2016) ISSN 2543-621X

117

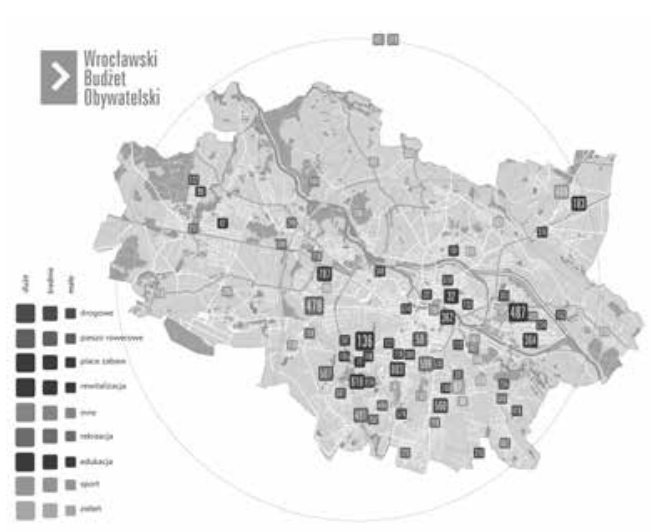

Rysunek 3

a 9 marca. W tym okresie zorganizowano 13 spotkań informacyjnych z mieszkańcami i dodatkowo 20 spotkań w ramach Laboratoriów Obywatelskich $^{42}$, w wybranych pięciu wrocławskich osiedlach. W tym czasie złożonych zostało 817 projektów w trzech progach kwotowych - projekty małe do 150 tys. zł; średnie do 500 tys. zł i duże do 2 mln zł. Rozmieszczenie projektów na mapie Wrocławia pokazuje rysunek 3. Widać na nim, ile projektów w poszczególnych progach zostało zgłoszonych przez mieszkańców [rysunek 3]. Po raz kolejny największa liczba projektów dotyczyła szeroko rozumianej rekreacji i zieleni. Na drugim miejscu, podobnie jak przed rokiem, plasowały się projekty drogowe, rowerowe i piesze.

Od 10 marca do 22 maja trwała weryfikacja projektów. Odbywała się ona na zasadach identycznych jak w poprzedniej edycji. Po jej zakończeniu liderzy zostali poinformowani o wynikach i zaproszeni na spotkania weryfikacyjne. Trwały one do 30 czerwca, a czas na ostateczne poprawienie projektów mijał 13 lipca. Następnie poprawione projekty były kolejny raz weryfikowane,
41. http://www.wroclaw.pl/informacje-z-dzialalnosci-rady. 42. O tym projekcie więcej piszę poniżej. 
zajmowała się nimi rada WBO. W dalszej kolejności lista projektów pozytywnie zweryfikowanych stała się załącznikiem do uchwały rady miejskiej, zarządzającej konsultacje i określającej termin głosowania. To ostatnie trwało pomiędzy 28 września a 12 października. Prócz nowej wysokości progów nowością w głosowaniu było minimum głosów, jakie musiał zebrać projekt, aby mógł trafić do realizacji.

W głosowaniu wzięło udział łącznie 168278 osób, w tym przez Internet głosowało 127648 osób a w formie papierowej 40630 osób. Tym samym Wrocław trafił do absolutnej czołówki polskich miast zarówno pod względem liczby głosujących (wyłącznie osoby pełnoletnie), jak i procentowego udziału głosujących w stosunku do liczby osób uprawnionych. Wyniki głosowania pierwszy raz zaprezentowane zostały zarówno w formie otwartych danych, jak i wykresów statystycznych obrazujących dynamikę głosowania i wiele innych cennych elementów. Do realizacji skierowano 79 projektów.

\section{Kontrowersje}

Efektem realizacji projektu małego, do 100000 zł, który w głosowaniu uzyskał tylko 11 głosów, była duża liczba projektów małych zgłaszanych przez mieszkańców. Bardzo często mieszkańcy na etapie weryfikacji prosili, aby ich projekty ograniczyć kwotowo tak, aby zmieściły się w najniższym progu kwotowym. Takie działania, choć miały wpływ na ilość środków przyznanych na ten najniższy próg kwotowy, to nie miały szans zagwarantowania realizacji wszystkim projektom - jak to miało miejsce w poprzednim roku.
Po zakończeniu głosowania urzędnicy zajmujący się procesem skierowali doniesienie do prokuratury o podejrzeniu popełnienia przestępstwa w związku z 14 przypadkami wykorzystania w głosowaniu danych osobowych przez osoby trzecie. Ta sprawa była podnoszona przez mieszkańców jako argument za tym, aby kolejne głosowanie przeprowadzić w sposób dający mieszkańcom jeszcze większe poczucie bezpieczeństwa, jeśli chodzi o ich dane osobowe.

Elementem, który wzbudził dyskusję, był zakończony sukcesem udział w głosowaniu projektów na terenie jednostek edukacyjnych. Rekordziści zebrali ponad 14 tys. głosów. Mimo iż projekty te dotyczyły budowy ogólnodostępnych boisk sportowych, część mieszkańców uznała że nie jest właściwe, aby placówki edukacyjne tak czynnie włączały się do głosowania. Pojawiły się też zarzuty, że niektóre szkoły zaczęły zbierać dane osobowe jeszcze przed rozpoczęciem głosowania. Dyskusja ta toczyła się w mediach społecznościowych i w niewielkim stopniu w prasie lokalnej. Po jej drugiej stronie było 12 tego typu wybranych do realizacji projektów i uzyskane ok. 70 tys. głosów. Równocześnie te tzw. szkolne projekty w rzeczywistości polegały wyłącznie na budowie ogólnodostępnych boisk, często w ścisłej zabudowie miejskiej, zlokalizowanych na terenach edukacyjnych. Obiekty te będą pod nadzorem administracji szkół, będą przez te szkoły porządkowane i utrzymywane, niektóre z nich mają własne oświetlenie - również utrzymywane przez placówki edukacyjne. Ale po godzinach

Miasto. Pamięć i Przyszłość 1 (2016) ISSN 2543-621X 


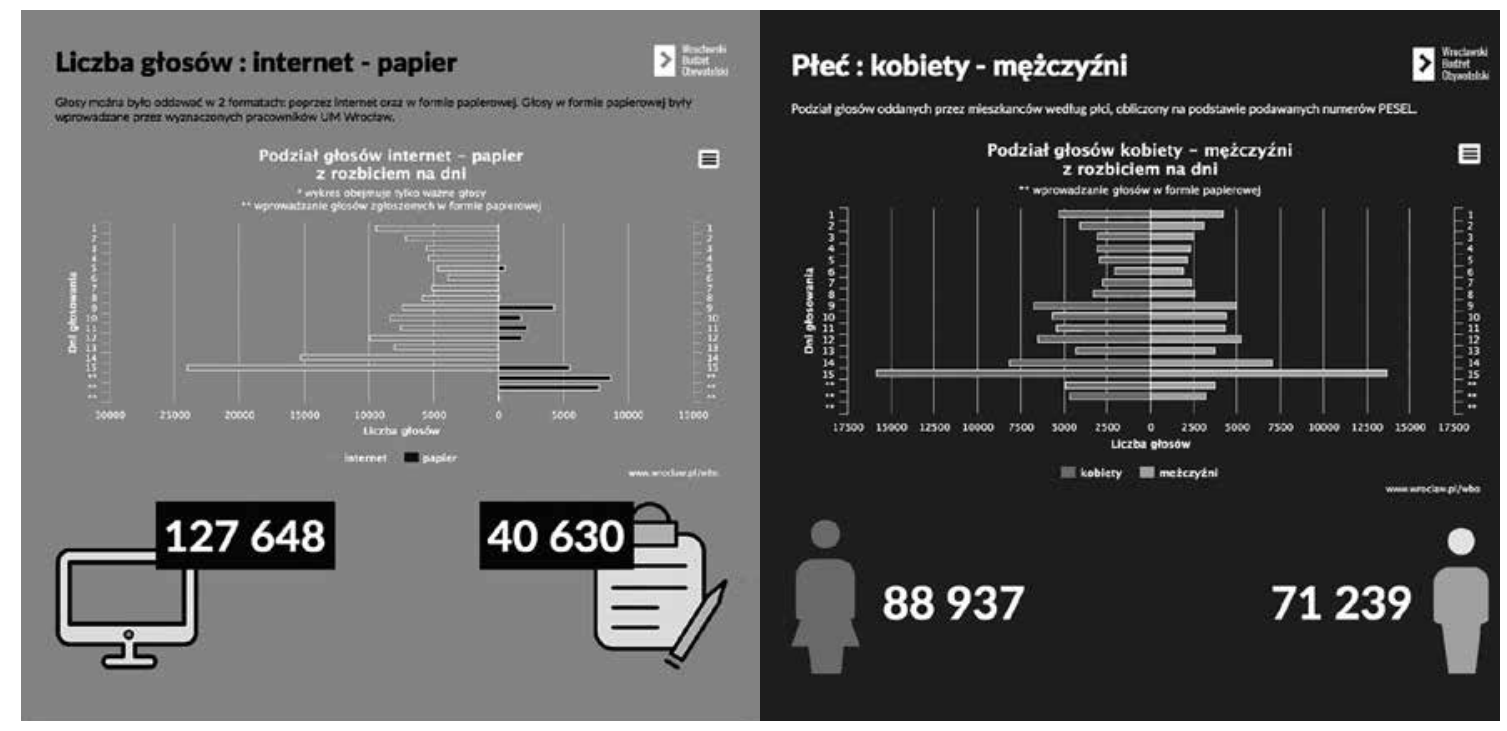

Rysunek 4

pracy jednostek, w weekendy, święta i wakacje mogą być wykorzystywane przez mieszkańców.

\section{Laboratoria Obywatelskie}

Czym są Laboratoria Obywatelskie? Nazwę tę wymyślił Łukasz Medeksza, członek Towarzystwa Urbanistów Polskich o. Wrocław. Na stronie wroclaw.pl pojawił się taki ich opis: „Przyjdź, zaproponuj lokalny projekt, przegadaj go z sąsiadami i urzędnikami. Buduj porozumienia na rzecz najciekawszych propozycji zgłoszonych na Twoim osiedlu"43. I wydaje się, że najlepiej określa on to narzędzie.

LO polegały na zorganizowaniu i przeprowadzeniu serii spotkań z mieszkańcami danego osiedla, we współpracy urzędu i grup aktywnych mieszkańców. Zorganizowano je na 5 osiedlach: Szczepin, Oporów, Sępolno-Biskupin-Dąbie-Bartoszowice, Brochów i Borek. W organizację każdego z nich włączył się inny podmiot: samorząd

Miasto. Pamięć i Przyszłość 1 (2016) ISSN 2543-621X

119 osiedlowy, NGO, Muzeum Współczesne Wrocław, aktywiści miejscy. Strategicznym partnerem urzędu przy ich organizacji były Towarzystwo Urbanistów Polskich o. Wrocław i Instytut Rozwoju Terytorialnego. Strategiczny partner odpowiadał za metodę Planning for Real, za pomocą której prowadzone były spotkania.

Metoda P4R zakładała pracę na makiecie osiedla, przygotowanej wcześniej przez dzieci z lokalnych - osiedlowych szkół. Mieszkańcy zaznaczali na niej obszary, w których widzieli konieczność wprowadzania zmian. Następnie na kolejnych spotkaniach dyskutowali o tych zmianach i opisywali je w formie projektów do WBO.

LO były niewątpliwym sukcesem. Zarówno pod względem frekwencyjnym, jak i możliwości aktywizacji i integracji lokalnych społeczności. Choć trzeba w tym miejscu zaznaczyć, że nie w każdym miejscu ich przebieg wyglądał

43. http://www.wroclaw.pl/rozmawia/laboratoria-obywatelskie dostęp 
podobnie. Były obszary (Szczepin) w których nie udało się zachęcić mieszkańców do uczestnictwa w tym projekcie. Co więcej, jego realizacja spotkała się z dużą niechęcią ze strony samorządu osiedlowego i największej w okolicy spółdzielni mieszkaniowej. Niemniej jednak w pełni sprawdziła się pewna reguła polegająca na tym, że takie spotkania mają szanse powodzenia tylko wówczas, kiedy zaangażuje się w nie silny i dobrze zakorzeniony w lokalnej społeczności partner.

Równocześnie należy w tym miejscu zauważyć, że organizacja tak dużej liczby spotkań z mieszkańcami w różnych obszarach miasta wymagała ogromnego zaangażowania ze strony urzędników. Odbycie niemal 20 spotkań w ciągu dwóch miesięcy, skonstruowanie pięciu makiet osiedli z budynkami, drzewami itp. pokazuje skalę tego przedsięwzięcia.

\section{Realizacja}

Od roku 2015 wszystkie zrealizowane w ramach WBO projekty są sygnowane znakami identyfikacyjnymi. Jest to z jednej strony podkreślenie, że projekt powstał dzięki zaangażowaniu mieszkańców, z drugiej, promocja idei budżetu partycypacyjnego. Jeśli chodzi o nadzór nad realizacją projektów, to wyglądał on tak jak w latach poprzednich. Pewnym wyróżnieniem tej edycji była realizacja projektu $\mathrm{nr} 280^{44}$. Zlecenie wykonania dokumentacji poprzedziły warsztaty zorganizowane w galerii BWA Dizajn. Ich efektem były trzy projekty w trzech lokalizacjach. Do mieszkańców należał wybór ostatecznej wersji i miejsca ulokowania napisu. Mogli to zrobić w głosowaniu elektronicznym, które trwało tydzień.

Realizacja projektów wybranych w WBO2015 zakończy się zapewne w roku 2017. Ok. 80\% projektów jak co roku zostanie zrealizowanych do końca 2016 r.

\section{Ewaluacja}

Zmiany w WBO poprzedzone zostały kolejnymi konsultacjami. Trwały one pomiędzy $16 \mathrm{li}$ stopada a 5 grudnia. Mieszkańcy zgłosili ponad 100 uwag i pomysłów. Wszystkie zostały przeanalizowane i zaprezentowane na spotkaniach, a także przepracowane z mieszkańcami w trakcie warsztatów. Wynikające z tej pracy zmiany nie były rewolucyjne. W ocenie mieszkańców zasady WBO są znane i czytelnie prezentowane. Pokazują to wyniki badania ankietowego, które przeprowadzono na ok. 14 tys. mieszkańców w trakcie trwania głosowania WBO. Podjęto na tej podstawie decyzję o niezmienianiu ogólnej ramy zasad.

Zmiany w kolejnej edycji miały dotyczyć kilku obszarów. Po pierwsze, większa kwota, która miała wynieść $25 \mathrm{mln}$ zł. Po drugie podział miasta na rejony i przyporządkowanie im konkretnych kwot. Każdy z 14 rejonów otrzymał po 1,5 mln zł. Dodatkowo 4 mln zł przeznaczono na projekty ogólnomiejskie, czyli takie, które dotyczą więcej niż jednego rejonu. Liczba rejonów ustalono po warsztatach z mieszkańcami. Rejony, choć nie reprezentują podobnej powierzchni czy ilości mieszkańców, miały ułatwić współpracę mieszkańcom osiedli. Mały być ze sobą skomunikowane/połączone, miały liczyć 


\section{Czy znasz zasady Wrocławskiego Budżetu Obywatelskiego?}

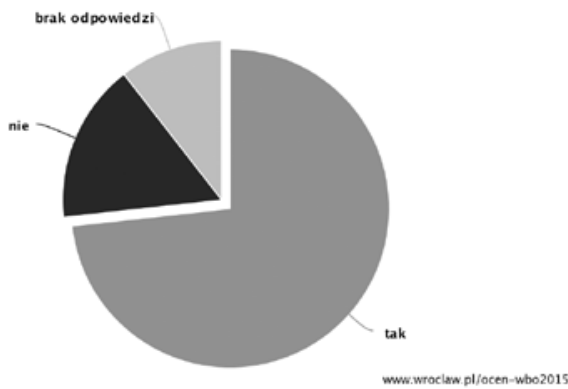

5. Czy Twoim zdaniem zasady Wrocławskiego Budżetu Obywatelskiego są:

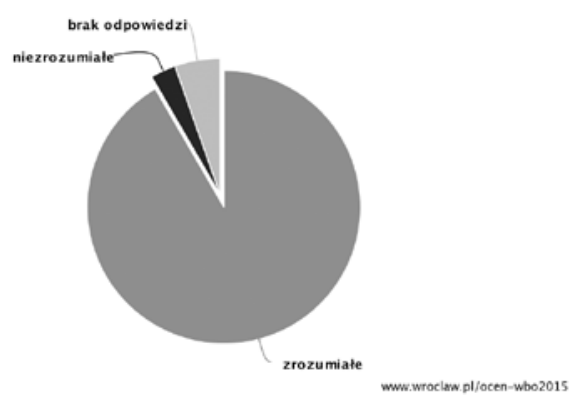

Rysunek 5

od 2 do 4 osiedli. W każdym rejonie ustalono takie same kwoty na projekty duże - maksimum 750 tys. zł i małe - maksimum 250 tys. zł. Maksymalną kwotą na projekt ogólnomiejski był $1 \mathrm{mln}$ zł. Trzecią istotną zmianą było dopuszczenie do głosowania osób od 16. roku życia. Ważnym powodem do wprowadzenia tej zmiany był też fakt, że we Wrocławiu od dwóch lat realizowany jest Młodzieżowy Budżet Obywatelski, adresowany do uczniów szkół. Projekt ten cieszy się sporym zainteresowaniem i jeśli WBO ma budować postawy obywatelskie, wydaje się naturalne, że powinien dążyć do angażowania młodzieży.

Ostatnim elementem, który wymagał odrębnego omówienia w trakcie ewaluacji, była kwestia ochrony danych osobowych. Skutkiem opisanego wcześniej doniesienia do prokuratury, sygnałów o zbieraniu danych osobowych na listach, a potem przepisywania ich było, po pierwsze, skrócenie głosowania do 11 dni, w tym dwóch weekendów. Po drugie, wdrożenie skutecznej metody uniemożliwiającej

Miasto. Pamięć i Przyszłość 1 (2016) ISSN 2543-621X

121 wprowadzanie głosów do systemu informatycznego. W tym celu zdecydowano się na zastosowanie SMS jako dodatkowego zabezpieczenia głosowania.

\section{WBO 2016}

WBO2016 wystartował z początkiem stycznia 2016 r., tradycyjnie od rozpoczęcia zbierania projektów. Tym razem projekt już od początku prowadzony był jedynie przez pracowników Biura Partycypacji Społecznej. Na zgłaszanie pomysłów mieszkańcy mieli czas do początku marca. Wpłynęło ich w sumie 791. Weryfikacja prowadzona była analogicznie jak w latach poprzednich i uczestniczyły w niej wszystkie merytoryczne jednostki. Po dwóch etapach weryfikacji, na liście do głosowania zostało ok. 450 projektów. Tyle zostanie poddane pod głosowanie mieszkańców ${ }^{45}$. Odbędzie się ono pomiędzy 30 września a 10 października.

Głosowanie, podobnie jak całe WBO, różni się dość istotnie od poprzednich edycji. Jak ustalono na etapie ewaluacji poprzedniego procesu, Wrocław został podzielony na 14 rejonów. Każdemu
45. W chwili kiedy powstawał ten tekst, do rozpoczęcia głosowania WBO pozostało ok. miesiąca. 
z nich przypisano 1,5 mln zł Dodatkowo przyporządkowano 4 mln zł na projekty ogólnomiejskie, czyli takie, które dotyczą więcej niż jednego rejonu. W rejonie mieszkańcy mogą głosować na jeden projekt lokalny duży - do 750 tys. zł i jeden mały - do 250 tys. zł. Dodatkowo moga oddać głos na dwa projekty ogólnomiejskie. To oznacza, że do realizacji w jednym rejonie trafi tyle projektów dużych, ile zmieści się w kwocie 750 tys. zł i tyle projektów małych, ile również zmieści się w kwocie 750 tys. zł. Taki sposób dystrybucji środków zdaniem urzędników powinien zagwarantować w każdym z rejonów realizację przynajmniej jednego projektu dużego i trzech projektów małych. Biorąc pod uwagę, że każdy mieszkaniec może oddać głos jedynie na dwa projekty rejonowe, powinno to spowodować większe rozproszenie głosów w rejonie i uniemożliwić jednej silnej grupie zagarnięcie całej puli rejonowej. Jeśli chodzi o projekty ogólnomiejskie, to zostanie ich zrealizowanych nie mniej niż cztery.

Rok 2016 to także pilotażowa realizacja "Gry o Budżet"46. Narzędzie to ${ }^{47}$ daje możliwość przedyskutowania każdego z projektów w gronie liderów, jak i mieszkańców. Daje możliwość zaprezentowania zalet i wad proponowanego pomysłu, ale dyskusja równocześnie może być dla liderów wskaźnikiem, jak powinni zmodyfikować swój projekt według wskazań

46. O "Grze o Budżet" więcej można przeczytać na stronach organizatorów http://graobudzet.crs.org.pl/o-grze/

47. We Wrocławiu narzędzie zostało opracowane i pilotażowo przeprowadzone przez Centrum Rozwiązań Systemowych https:// crs.org.pl/

48. Autor miał na myśli korelację między opublikowaniem wyników pierwszej weryfikacji a terminami 14 spotkań z mieszkańcami 49. Samych spotkań weryfikacyjnych zorganizowano w czerwcu aż 14. mieszkańców. Biuro Partycypacji Społecznej zorganizowało dwie takie gry. Jedną o charakterze ogólnomiejskim, a drugą lokalnym. Obie zostały przeprowadzone w czerwcu. Obie miały za zadanie przetestować to narzędzie w realiach wrocławskich. Mimo promocji tego pilotażu wśród liderów i pozostałych mieszkańców GoB nie spotkała się z dużym zainteresowaniem i odzewem. Jednym z powodów był zapewne przedwakacyjny termin - wynikał on z kalendarza WBO i przez to nie mógł podlegać modyfikacjom ${ }^{48}$. Drugim powodem mogło być przesycenie spotkaniami z mieszkańcami w czerwcu ${ }^{49}$ oraz fakt, że sama gra nie miała większego wpływu na dalsze procedowanie projektów z WBO. Mieszkańcy nie czuli zatem ani obowiązku, ani korzyści z tego, aby wziąć udział w projekcie.

\section{WBO... i co dalej?}

Wrocławski Budżet Obywatelski od chwili powstania ma zaszyty w sobie moduł przyszłości. Projekt ten ma sens tylko wówczas, kiedy widzi się go przez pryzmat lat, które mają dopiero nastąpić. Z tego powodu przyszłość WBO jest dość prosta do opisania, z jednym „ale”. Polega ono na tym, że bardzo dużo w tym procesie zależy od mieszkańców, którzy co roku mają możliwość zgłoszenia obszarów do zmian. Poniżej zapisane są zatem wyłącznie te działania, nad którymi już pracują urzędnicy z BPS.

Po pierwsze, Laboratoria Obywatelskie powinny mieć swój ciąg dalszy. Sukces tego projektu wyznacza i determinuje oczywisty kierunek na przyszłość. Potrzebni są jednak do ich

Miasto. Pamięć i Przyszłość 1 (2016) ISSN 2543-621X 
prowadzenia lokalni partnerzy, których trzeba pozyskać, przeszkolić, wyposażyć w narzędzia do pracy z mieszkańcami.

Po drugie, konieczne jest wypełnianie inwestycji stworzonych dzięki WBO działaniami mieszkańców. Inspirowanie mieszkańców i dawanie im narzędzi do tego, aby budowane parki, place zabaw czy boiska sportowe jeszcze bardziej spełniały swoją aktywizacyjną rolę i pracowały na rzecz lokalnego społeczeństwa obywatelskiego. I temu celowi służyć mogą "małe granty”, projekt, nad którym BPS pracuje z wrocławskimi NGO. Ma on polegać na przekazywaniu mieszkańcom drobnych kwot pieniężnych, które mają służyć organizacji różnych przedsięwzięć z wykorzystaniem infrastruktury wybudowanej w ramach WBO. Cały proces ma być konkurencyjny i wymuszający współpracę między mieszkańcami.

Po trzecie, realizując kolejne edycje WBO, dojdziemy w końcu do momentu nasycenia miasta np. boiskami, siłowniami na wolnym powietrzu czy drogami rowerowymi. Dlatego warto promować szerokie myślenie o przestrzeni wspólnej. Można robić to poprzez LO. Ale można też przez wstępne wskazywanie obszarów, w których mieszkańcy mogą budować swoim zaangażowaniem tereny służące lokalnym wspólnotom. Być może pewnym pomysłem jest poprzedzanie realizacji projektów z WBO pogłębionymi dyskusjami, warsztatami czy konsultacjami z jak najszerszymi grupami przyszłych odbiorców?

Po czwarte, kwota przeznaczana na WBO nie powinna rosnąć w nieskończoność. Siłą i celem
WBO jest budowanie aktywności mieszkańców. Realizacja projektu jest swoistą premią za aktywność i spełnieniem marzeń o wypełnieniu lokalnej przestrzeni istotną dla mieszkańców funkcją. Ale sama dyskusja między mieszkańcami, integracja przy wymyślaniu tej przestrzeni, praca nad promocją projektu czy zbieraniem głosów - to są tak naprawdę najważniejsze elementy aktywizacji mieszkańców. I to ich wspieraniu ma służyć WBO. Właśnie dlatego kwota na WBO w pewnym momencie przestanie rosnąć. Kiedy to się stanie? Wtedy, kiedy wypracujemy najsprawniejszy schemat zgłaszania, dyskusji i głosowania. Ale to równocześnie oznacza, że możliwości wpływania mieszkańców na ich otoczenie powinno być więcej. Pewnego rodzaju uzupełnieniem WBO mogłyby się stać Karty Zadań Inwestycyjnych, zgłaszane co roku przez samorządy osiedlowe.

\section{Podsumowanie}

WBO to zaplanowana i ściśle realizowana strategia otwierania miasta. Od pierwszej, pilotażowej edycji, której zadaniem było zaprezentowanie i jak najszersze przedyskutowanie tego pomysłu, mieszkańcami, po kolejne edycje, które miały rozpropagować WBO wśród mieszkańców, wypracować najwłaściwsze i najbardziej efektywne metody realizacji tego projektu. Wreszcie ostateczne sformatowanie zespołu, który zajmuje się obecnie nie tylko WBO, ale i konsultacjami z mieszkańcami oraz współpracą z NGO - pokazuje wyraźny kierunek zmian we Wrocławiu.

WBO jest projektem, co zostało już zauważone na początku niniejszej rozprawy, którego głównymi celami jest aktywizacja mieszkańców, edukacja 
- zarówno mieszkańców odnośnie do mechanizmów funkcjonowania miasta, jak i urzędników w zakresie potrzeb mieszkańców. I na szczycie opisanej piramidy mamy realizację - wykonanie projektów/inwestycji. Najbardziej widoczny element, wisienka na torcie, ale równocześnie element będący na samym końcu procesu. Dosłownie i w przenośni. WBO pozwala mieszkańcom na kreowanie otaczającej ich przestrzeni. Ale uczy ich też dyskusji, miasta i angażowania się w lokalne społeczności. Dlatego tak ważne jest choćby docieranie do osób młodych, które dopiero będą wchodzić w dorosły świat.

WBO jest projektem wpisującym się w trend smart cities. Narzędzia do komunikacji z mieszkańcami, interaktywny sposób składania projektów, pozyskiwania informacji o weryfikacji, dyskusji o projektach czy wreszcie głosowania i publikacji danych w formie open data - to wszystko nieodłączne elementy WBO. Ale oprócz tego, co widzą i z czego korzystają mieszkańcy, są jeszcze elementy niewidoczne dla nich, ale za to bardzo ułatwiające pracę urzędnikom. Elektroniczny system obiegu projektów, nadzór nad ich realizacją i komunikacja między tymi systemami - to kolejne elementy smart, wyróżniające wrocławski budżet partycypacyjny na tle innych, podobnych rozwiązań w Polsce.

WBO jest wreszcie projektem, który mocno przyczynił się do otwarcia dyskusji o Wrocławiu. Te dyskusje często są trudne zarówno dla mieszkańców, jak i urzędników. Ale kiedy prowadzone są z zaangażowaniem, według ustalonych zasad, udaje się stworzyć wspólnie z mieszkańcami ciekawą przestrzeń. Przestrzeń, którą warto rozwijać i wykorzystywać do budowania lokalnych społeczności. I właśnie nacisk na poszerzanie pola debaty publicznej to specyfika wrocławskiego budżetu partycypacyjnego. Specyfika widoczna mocno od pilotażu w roku 2013 aż do dziś.

\footnotetext{
Bartłomiej Świerczewski 1996-2001 studia magisterskie - Uniwersytet Wrocławski; Wydział Nauk Historycznych i Pedagogicznych; kierunek Historia. 1999-2000 Filologia Słowiańska - j. ukraiński - Uniwersytet Wrocławski. 2001-2007 Studium doktoranckie - Uniwersytet Wrocławski; zakończone obrona pracy doktorskiej [pod kierunkiem prof. Wojciecha Wrzesińskiego] z wyróżnieniem. 2008-2009 Podyplomowe studia z zarzadzania projektami - Wyższa Szkoła Bankowa we Wrocławiu. Od 2000 pracuję w Urzędzie Miejskim Wrocławia. Zaczynałem w Biurze Prezydenta Wrocławia, następnie wiele lat samorzadu uczyłem się w Biurze Rady Miejskiej Wrocławia a od 2014r. jestem dyrektorem Biura ds. Partycypacji Społecznej. Obecnie koordynuję tematy dotyczace NGO, konsultacji - czyli szeroko rozumianej partycypacji społecznej. Od roku 2013 koordynuję proces Wrocławskiego Budżetu Obywatelskiego. Wdrażałem ten projekt we Wrocławiu i rozwijam go we współpracy z mieszkańcami. Prywatnie - wrocławianin od urodzenia, ojciec trójki dzieci, pasjonat gór i ciszy.
}

Miasto. Pamięć i Przyszłość 1 (2016) ISSN 2543-621X 
Bibliografia:

\section{Źródła internetowe}

http://bp.partycypacjaobywatelska.pl/

https:// crs.org.pl/

https://en.wikipedia.org/wiki/Porto_Alegre

http://www.gazetawroclawska.pl/arty-

kul/786343,dutkiewicz-do-wydania-sa-2-mln-zl-

-wroclawianie-zdecyduja-na-co-glosuj,id,t. html.

http://www.gazetawroclawska.pl/arty-

kul/787314,budzet-obywatelski-kwota-jest-niepo-

wazna-a-wroclaw-mami-opinie-publiczna-list,id,t.

html.

http://www.gazetawroclawska.pl/arty-

kul/911886,glosowanie-nad-projektami-budzetu-

-obywatelskiego-niewazne,id,t.html.

http://graobudzet.crs.org.pl/o-grze/

http://www.parkmamuta.pl/

http://www.krytykapolityczna.

pl/kluby-kp/wroclaw/20130329/

partycypacja-nie-konkurs-grantowy.

https://mac.gov.pl/budzet-partycypacyjny

http://uchwaly.um.wroc.pl/uchwala.

aspx?numer=XIX/387/15

http://uchwaly.um.wroc.pl/uchwala.

aspx?numer=XLIV/1074/13

http://uchwaly.um.wroc.pl/uchwala.

aspx?numer=XXXVII/2437/05

http://uchwaly.um.wroc.pl/uchwala.

aspx?numer $=231 / 15$

http://uchwaly.um.wroc.pl/uchwala.

aspx?numer=LXII/1579/14

http://wroclaw.wyborcza.pl/wroc-

law/1,35771,13857324,Obywatelu_zawalcz_o_ swoj_wniosek_do_budzetu_obywatelskiego_. Html http://wroclaw.wyborcza.pl/wroc-

law/1,36743,13643913,Obywatelski_czy_partycypa- cyjny_na_ile_i_czy_rzeczywiscie_html

http://wroclaw.wyborcza.pl/wroc-

law/1,35771,13681326,Prawdziwy_budzet_obywatelski_czy_raczej_totolotek_html.

http://www.wroclaw.pl/ co-nowego-we-wroclawskim-budzecie-obywatelskim

http://www.wroclaw.pl/ przyszlosc-wroclawskiego-budzetu-obywatelskiego

http://www.wroclaw.pl/zasady-wbo-na-2014-rok http://www.wroclaw.pl/rozmawia/ centra-informacyjne-wbo.

http://www.wroclaw.pl/rozmawia/

wbo-2014-zasady

http://www.wroclaw.pl/files/files/WBO_pomys-

ly_i_uwagi_zgloszone_w_roku_2014.pdf

http://www.wroclaw.pl/

informacje-z-dzialalnosci-rady.

. http://www.wroclaw.pl/rozmawia/laboratoria-obywatelskie dostęp

https://www.wroclaw.pl/budzet-obywatelski-wroclaw/ wbo2016/projekty-2015/projekt,id,280 http://tumw.pl/ wroclawski-budzet-obywatelski-2014-nasza-opinia/\#more-4592.

\section{Pozostałe}

72 Frequently Asked Questions about Participatory Budgeting, http://unhabitat.org/ books /72 - frequently-asked-questionsabout-participatory-budgeting

Deepti Bhatnagar, Animesh Rathore, Magüi Moreno Torres, Parameeta Kanungo, Participatory budgeting in Brazil http://siteresources.worldbank. org/INTEMPOWERMENT/Resources/14657_Partic-Budg-Brazil-web.pdf

Porto Alegre and the participatory budget: civic education, politics and the possibilities for replication, http://fimforum.org/en/library/ 
Porto_Alegre_and_the_Participatory_Budget.pdf

Rocznik statystyczny Wrocławia 2014, http://wroc-

law.stat.gov. pl/publikacje-i-foldery/roczniki-statystyczne/rocznik-statystyczny-wroclawia-2014,3,2. html

Szaranowicz-Kusz M., Budżet partycypacyjny w Polsce, http://orka.sejm.gov.pl/WydBAS. nsf/0/ E2A1331AC540CD42C1257F3F00432714/\$file/ Infos_205. pdf. 